\title{
Front Matter: Volume 10943
}

, "Front Matter: Volume 10943," Proc. SPIE 10943, Ultra-High-Definition Imaging Systems II, 1094301 (15 May 2019); doi: 10.1117/12.2531374

SPIE. Event: SPIE OPTO, 2019, San Francisco, California, United States 


\title{
PROCEEDINGS OF SPIE
}

\section{Ultra-High-Definition Imaging Systems II}

\author{
Seizo Miyata \\ Toyohiko Yatagai \\ Yasuhiro Koike \\ Editors
}

2-3 February 2019

San Francisco, California, United States

Sponsored and Published by

SPIE

Volume 10943 
The papers in this volume were part of the technical conference cited on the cover and title page. Papers were selected and subject to review by the editors and conference program committee. Some conference presentations may not be available for publication. Additional papers and presentation recordings may be available online in the SPIE Digital Library at SPIEDigitallibrary.org.

The papers reflect the work and thoughts of the authors and are published herein as submitted. The publisher is not responsible for the validity of the information or for any outcomes resulting from reliance thereon.

Please use the following format to cite material from these proceedings:

Author(s), "Title of Paper," in Ultra-High-Definition Imaging Systems II, edited by Seizo Miyata, Toyohiko Yatagai, Yasuhiro Koike, Proceedings of SPIE Vol. 10943 (SPIE, Bellingham, WA, 2019) Sevendigit Article CID Number.

ISSN: 0277-786X

ISSN: 1996-756X (electronic)

ISBN: 9781510625280

ISBN: 9781510625297 (electronic)

Published by

SPIE

P.O. Box 10, Bellingham, Washington 98227-0010 USA

Telephone +1 3606763290 (Pacific Time) · Fax +1 3606471445

SPIE.org

Copyright @ 2019, Society of Photo-Optical Instrumentation Engineers.

Copying of material in this book for internal or personal use, or for the internal or personal use of specific clients, beyond the fair use provisions granted by the U.S. Copyright Law is authorized by SPIE subject to payment of copying fees. The Transactional Reporting Service base fee for this volume is $\$ 18.00$ per article (or portion thereof), which should be paid directly to the Copyright Clearance Center (CCC), 222 Rosewood Drive, Danvers, MA 01923. Payment may also be made electronically through CCC Online at copyright.com. Other copying for republication, resale, advertising or promotion, or any form of systematic or multiple reproduction of any material in this book is prohibited except with permission in writing from the publisher. The CCC fee code is 0277 $786 \times / 19 / \$ 18.00$.

Printed in the United States of America by Curran Associates, Inc., under license from SPIE.

Publication of record for individual papers is online in the SPIE Digital Library.

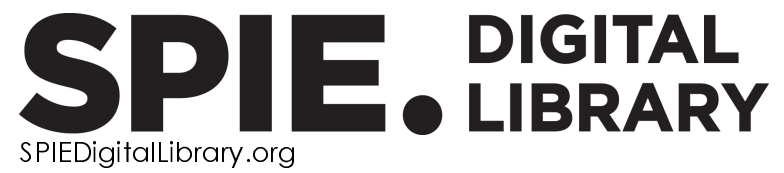

Paper Numbering: Proceedings of SPIE follow an e-First publication model. A unique citation identifier (CID) number is assigned to each article at the time of publication. Utilization of CIDs allows articles to be fully citable as soon as they are published online, and connects the same identifier to all online and print versions of the publication. SPIE uses a seven-digit CID article numbering system structured as follows:

- The first five digits correspond to the SPIE volume number.

- The last two digits indicate publication order within the volume using a Base 36 numbering system employing both numerals and letters. These two-number sets start with $00,01,02,03,04$, 05, 06, 07, 08, 09, OA, OB ... 0Z, followed by 10-1Z, 20-2Z, etc. The CID Number appears on each page of the manuscript. 


\section{Contents}

$\checkmark \quad$ Authors

vii Conference Committee

3D

$1094306 \quad$ Correlation of holograms for surface characterization of diffuse objects [10943-3]

IMAGING I

1094309 Real-time modulation transfer function measurement system (Invited Paper) [10943-6]

10943 OA Light field display using ultra-high-definition imaging device (Invited Paper) [10943-7]

IMAGING II

10943 OK High-resolution spatial light modulator on glass for digital holographic display (Invited Paper) [10943-28]

IMAGING III

10943 OL 17-inch 8K 120-Hz driving and BT.2020 color gamut LCDs with laser backlights (Invited Paper) [10943-16]

TRANSMISSION II

10943 OR High-efficiency see-through glasses with wavelength selective waveguide (Invited Paper) [10943-23]

\section{POSTER SESSION}

$10943 \mathrm{OU}$ Optic design and image processing considering angle of incidence via end-to-end optimization method [10943-26] 
Proc. of SPIE Vol. $109431094301-4$

Downloaded From: https://www.spiedigitallibrary.org/conference-proceedings-of-spie on 25 Apr 2023 Terms of Use: https://www.spiedigitallibrary.org/terms-of-use 


\title{
Authors
}

Numbers in the index correspond to the last two digits of the seven-digit citation identifier (CID) article numbering system used in Proceedings of SPIE. The first five digits reflect the volume number. Base 36 numbering is employed for the last two digits and indicates the order of articles within the volume. Numbers start with 00, 01, 02, 03, 04, 05, 06, 07, 08, 09, OA, OB...0Z, followed by 10-12, 20-2Z, etc.

\author{
Abeywickrema, U., 06 \\ Asakawa, Yoichi, OL \\ Banerjee, P. P., 06 \\ Bordbar, B., 06 \\ Cao, L., 06 \\ Cho, Jaebum, OU \\ Choi, Ji Hun, OK \\ Choi, Kyunghee, OK \\ Hwang, Chi-Sun, OK \\ Hwang, Chi-Young, OK \\ Iwane, Toru, OA \\ Jeong, Youngmo, OU \\ Kijima, Hiroaki, OL \\ Kim, Gi Heon, OK \\ Kim, Hee-OK, OK \\ Kim, Yong-Hae, OK \\ Komura, Shinichi, OL \\ Lee, Byoungho, ou \\ Lee, Won-Jae, OK \\ Lin, Zhang, OR \\ Lin, Xiao, OR \\ Masaoka, Kenichiro, 09 \\ Onoda, Ken, OL \\ $\mathrm{Pi}$, Jae-Eun, OK \\ Tan, Xiaodi, OR \\ Xiao, Xue, OR \\ Yang, Jong-Heon, OK \\ Yoo, Dong-Heon, OU \\ Zang, Jinliang, $\mathrm{OR}$ \\ Zhou, H., 06
}


Proc. of SPIE Vol. 10943 1094301-6

Downloaded From: https://www.spiedigitallibrary.org/conference-proceedings-of-spie on 25 Apr 2023 Terms of Use: https://www.spiedigitallibrary.org/terms-of-use 


\section{Conference Committee}

Symposium Chairs

Connie J. Chang-Hasnain, University of California, Berkeley (United States)

Graham T. Reed, Optoelectronics Research Centre, University of Southampton (United Kingdom)

Symposium Co-chairs

Sailing He, KTH Royal Institute of Technology (Sweden) and Zhejiang University (China)

Yasuhiro Koike, Keio University (Japan)

Program Track Chair

Liang-Chy Chien, Kent State University (United States)

Conference Chairs

Seizo Miyata, Tokyo University of Agriculture and Technology (Japan)

Toyohiko Yatagai, Utsunomiya University Center for Optical Research \& Education (Japan)

Yasuhiro Koike, Keio University (Japan)

Conference Program Committee

Liangcai Cao, Tsinghua University (China)

Janglin Chen, Industrial Technology Research Institute (Taiwan)

Ray T. Chen, The University of Texas at Austin (United States)

Toshio Chiba, Kairos Company, Ltd. (Japan)

Namho Hur, Electronics and Telecommunications Research Institute

(Korea, Republic of)

Azusa Inoue, Keio University (Japan)

Norihiko Ishii, NHK Japan Broadcasting Corporation (Japan)

Toru Iwane, Nikon Corporation (Japan)

Bahram Javidi, University of Connecticut (United States)

Kyuheon Kim, Kyung Hee University (Korea, Republic of)

Gauthier Lafruit, Université Libre de Bruxelles (Belgium)

Byoungho Lee, Seoul National University (Korea, Republic of)

Shiuan-Huei Lin, National Chiao Tung University (Taiwan)

Wolfgang Osten, Institut für Technische Optik (Germany)

No-Cheol Park, Yonsei University (Korea, Republic of)

Ifor D. W. Samuel, University of St. Andrews (United Kingdom) 
Mark Schubin, Hollywood Post Alliance (United States)

Okihiro Sugihara, Utsunomiya University (Japan)

Xiaodi Tan, Beijing Institute of Technology (China)

Kenkichi Tanioka, Medical Imaging Consortium (Japan)

Din Ping Tsai, Research Center for Applied Sciences - Academia Sinica (Taiwan)

Kenji Yamamoto, National Institute of Information and Communications Technology (Japan)

Hiromasa Yamashita, Kairos Company, Ltd. (Japan)

Whitney R. White, Chromis Fiberoptics Inc. (United States)

Session Chairs

1 Storage

Yasuhiro Koike, Keio University (Japan)

$23 \mathrm{D}$

Yasuhiro Koike, Keio University (Japan)

3 Imaging I

Ryushi Fujimura, Utsunomiya University (Japan)

4 Transmission I

Bernard Kippelen, Georgia Institute of Technology (United States)

5 Imaging II

Xiaodi Tan, Beijing Institute of Technology (China)

6 Imaging |II

Jong-Heon Yang, Electronics and Telecommunications Research Institute (Korea, Republic of)

7 Transmission II

Azusa Inoue, Keio University (Japan)

Toyohiko Yatagai, Utsunomiya University Center for Optical Research \& Education (Japan) 